\title{
HIWALAH DAN APLIKASINYA DALAM PRODUK BAI' AL-ISTISHNA' DI BANK SYARIAH
}

\author{
T. Abrar, ZA
}

\begin{abstract}
Abstrak
Hiwalah adalah pemindahan piutang dari tanggung jawab seseorang menjadi tanggung jawab orang lain. Prinsip hiwalah diaplikasikan di bank syariah dalam bentuk produk bai' al-istishna dan bai' al-salam. Produk bai' al-istishna merupakan mekanisme pertanggungan piutang oleh pihak bank syariah kepada pihak nasabah yang memiliki tanggungan utang atas pembiayaan proyek-proyek fisik. Bank syariah akan memperoleh keuntungan berdasarkan bagi hasil keuntungan dari proyek yang dikerjakan oleh pihak nasabah. Sedangkan produk bai' al-salam merupakan mekanisme pertanggungan piutang oleh pihak bank syariah kepada pihak nasabah yang melakukan suatu transaksi jual beli tidak secara tunai. Faktor-faktor pendukung pengembangan prinsip hiwalah dalam produk bai' al-istishna dan bai' al-salam di bank syariah adalah kinerja positif seluruh pimpinan, staf dan karyawan bank syariah memiliki komitmen kuat terhadap pengembangan ekonomi syariah, kemampuan manajerial yang baik, dan sikap mental (kejujuran) serta amanah untuk melayanan masyarakat sebaik-baiknya. Sedangkan faktor penghambatnya adalah masih rendahnya tingkat pemahaman masyarakat terhadap bank syariah, kurangnya sosialisasi hiwalah dalam produk bai' al-istishna dan bai' al-salam, masih lemahnya jaringan perbankan syariah dengan bank-bank lain serta belum optimalnya fasilitas pelayanan sistem jaringon antar bank online.
\end{abstract}

Kata Kunci: Hiwalah, bai’ al istisna', bank syariah

\section{A. Pendahuluan}

Salah satu produk unggulan bank syariah adalah bai' al-istishna' yang menerapkan prinsip hiwalah. Prinsip hiwalah merupakan produk jasa pemindahan tanggungan piutang oleh pihak bank syariah kepada pihak nasabah yang memiliki tanggungan piutang kepada pihak ketiga. Pada umumnya, hiwalah diaplikasikan di bank syariah dalam dua bentuk yakni bai' al-istishna dan bai' al-salam. Bank syariah terus berupaya melakukan berbagai terobosan yang salah satunya adalah menyediakan produk jasa keuangan dalam bidang pertanggungan piutang pembiayaan usaha yang disebut bai al-istishna berdasarkan prinsip hiwalah.

Sementara itu, bank syariah sebagai bank yang aktivitasnya meninggalkan masalah riba, gharar dan maisyir sesungguhnya menyediakan banyak produk 
alternatif di bidang keuangan syariah. Akan tetapi, masyarakat belum banyak mengetahui dan memahami bahwa hiwalah merupakan produk unggulan bank syariah yang dapat digunakan untuk berbagai transaksi bisnis dan investasi. Suatu hal yang sangat menggembirakan adalah belakangan ini telah tampak kesadaran dan motivasi masyarakat untuk berinvestasi atau menggunakan produk jasa keuangan di bank syariah lebih menguntungkan daripada bank konvensional.

Berkenaan dengan hal tersebut, tulisan ini akan menjelaskan tentang konsep hiwalah dan aplikasinya dalam produk bai' al-istishna di bank syariah. Melalui tulisan ini diharapkan memperoleh pemahaman dan gambaran baik secara teoritis maupun praktis tentang penerapan prinsip hiwalah di bank syariah secara mikro. Sekurang-kurangnya, tulisan ini akan mengkaji tentang pengertian, ketentuan hiwalah dalam hukum ekonomi Islam, aplikasi hiwalah dan bai al-istishna di bank syariah serta analisis pengembangan produk hiwalah dan bai' al-istishna di bank syariah. Hasil dari tulisan ini diharapkan dapat memberikan sumbangan bagi pengembangan konsep ekonomi syariah mikro dan aplikasinya yang bebas bunga dan berguna bagi upaya pembangunan ekonomi di Indonesia.

\section{B. Pengertian dan Dasar Hukum Hiwalah}

Menurut bahasa, hiwalah adalah al-intiqal dan al-tahwil berarti memindahkan atau mengoperkan, sedangkan menurut istilah berarti pemindahan piutang dari tanggung jawab seseorang menjadi tanggung jawab orang lain. Hal ini didasarkan kepada definisi yang disampaikan oleh al-Jaziri:

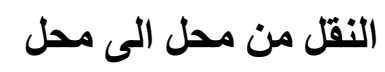

"Pemindahan hutang dari tanggung jawab orang yang berhutang kepada tanggung jawab orang lain"

Dalam pengertian yang lebih umum, hiwalah dapat didefinisikan sebagai suatu bentuk perjanjian yang dilakukan oleh tiga pihak, di mana tanggung jawab pembayaran piutang pihak pertama kepada pihak kedua ditanggung oleh pihak ketiga sesuai dengan kesepakatan. Dengan kata lain, dalam konteks ini ada empat unsur yakni ada pihak yang saling berpiutang (muhil), ada pihak penerima tanggungan 
piutang (rahn al-dayn), ada barang/harta yang ditanggung sebagai piutang (muhal 'alaih) dan kesepakatan pertanggungan piutang (ijab qabul) (Hendi Suhendi:1996).

Islam mengajarkan dalam al-Qur'an bahwa konsep pertanggungan piutang yang harus diikuti oleh para pelaku transaksi menekankan pada pertanggungjawaban sehingga perlu dicatat secara akurat sebagaimana ditegaskan dalam surat al-Baqarah ayat 282 yang berbunyi:

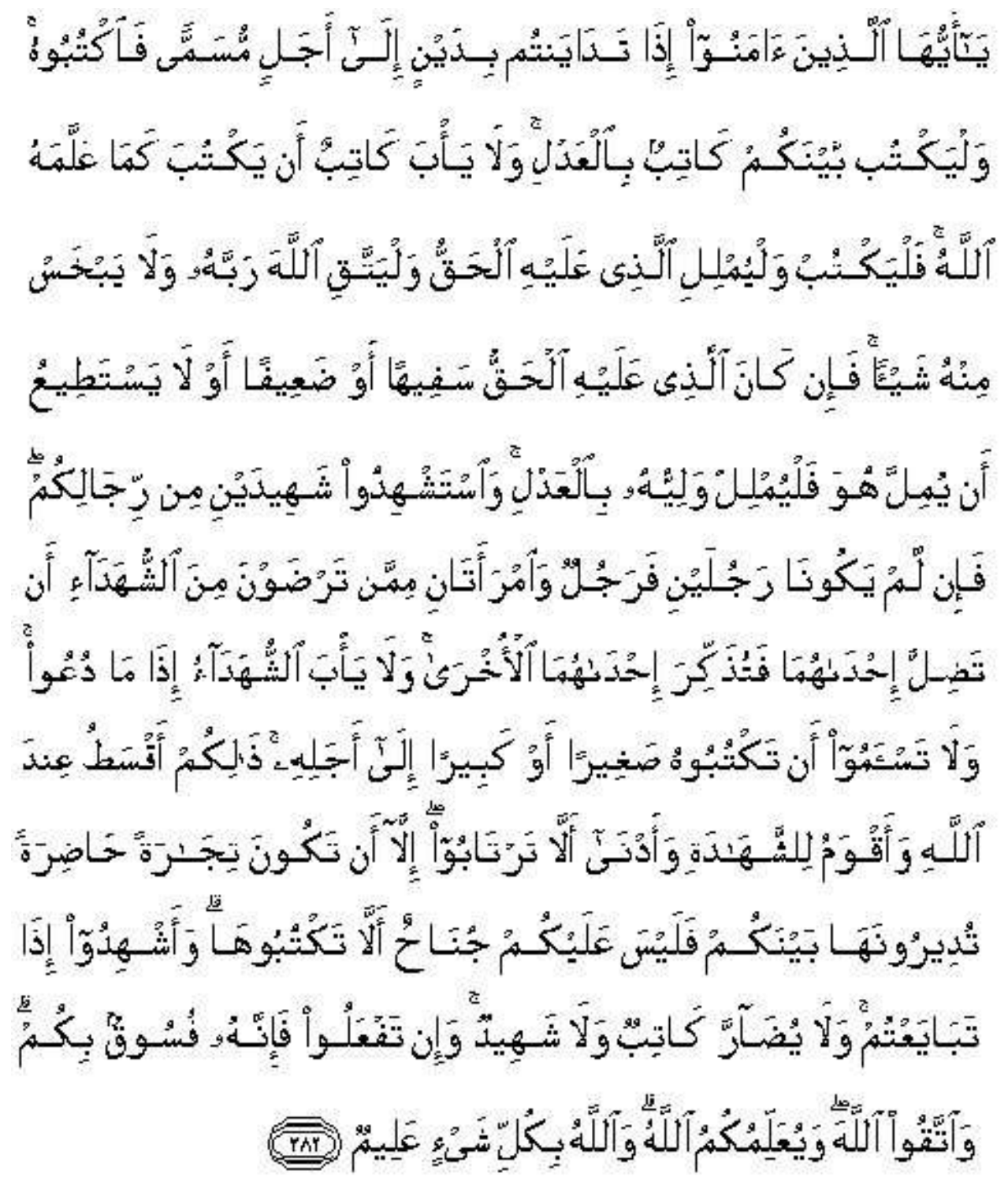

"Hai orang-orang yang beriman, apabila kamu bermuamalah tidak secara tunai untuk waktu yang ditentukan, hendaklah kamu menuliskannya. dan hendaklah seorang penulis di antara kamu menuliskannya dengan benar. dan janganlah penulis enggan menuliskannya sebagaimana Allah mengajar- 
kannya, meka hendaklah ia menulis, dan hendaklah orang yang berhutang itu mengimlakkan (apa yang akan ditulis itu), dan hendaklah ia bertakwa kepada Allah Tuhannya, dan janganlah ia mengurangi sedikitpun daripada hutangnya. jika yang berhutang itu orang yang lemah akalnya atau lemah (keadaannya) atau Dia sendiri tidak mampu mengimlakkan, Maka hendaklah walinya mengimlakkan dengan jujur. dan persaksikanlah dengan dua orang saksi dari orang-orang lelaki (di antaramu). jika tak ada dua oang lelaki, Maka (boleh) seorang lelaki dan dua orang perempuan dari saksi-saksi yang kamu ridhai, supaya jika seorang lupa Maka yang seorang mengingatkannya. janganlah saksi-saksi itu enggan (memberi keterangan) apabila mereka dipanggil; dan janganlah kamu jemu menulis hutang itu, baik kecil maupun besar sampai batas waktu membayarnya. yang demikian itu, lebih adil di sisi Allah dan lebih menguatkan persaksian dan lebih dekat kepada tidak (menimbulkan) keraguanmu. (Tulislah mu'amalahmu itu), kecuali jika mu'amalah itu perdagangan tunai yang kamu jalankan di antara kamu, Maka tidak ada dosa bagi kamu, (jika) kamu tidak menulisnya. dan persaksikanlah apabila kamu berjual beli; dan janganlah penulis dan saksi saling sulit menyulitkan. jika kamu lakukan (yang demikian), Maka Sesungguhnya hal itu adalah suatu kefasikan pada dirimu. dan bertakwalah kepada Allah; Allah mengajarmu; dan Allah Maha mengetahui segala sesuatu"

Implementasi ketentuan ayat di atas dalam operasional bank syariah adalah dengan menerapkan prinsip hiwalah dalam produk bai' al-istishna dan bai' al-salam. Penggunakan hiwalah sebagai salah satu prinsip dalam produk bai' al-istishna dan bai' al-salam sedikit berbeda (M. Syafi'i Antonio: 2001). Pertama, bai' al-istishna merupakan mekanisme pertanggungan piutang oleh pihak bank syariah kepada pihak nasabah yang memiliki tanggungan utang atas pembiayaan proyek-proyek fisik. Dalam hal ini, bank syariah akan memperoleh keuntungan berdasarkan bagi hasil keuntungan dari proyek yang dikerjakan oleh pihak nasabah. Kedua, bai' al-salam merupakan mekanisme pertang-gungan piutang oleh pihak bank syariah kepada pihak nasabah yang melakukan suatu transaksi jual beli tidak secara tunai.

Makna pertama mengandung pengertian bahwa apabila nasabah tidak memiliki uang tunai (cash) untuk membiayai proyek, maka bank syariah secara otomatis akan menjadi pihak penjamin piutang atas biaya proyek yang harus dibayar oleh nasabah (perorangan/badan hukum). Disebabkan adanya kesepakatan besaran angka dan batas waktu dalam pembayaran piutang, maka bank syariah memiliki hak mendapatkan kelebihan ( $f e e$ atau mark up) dari keuntungan pembiayaan proyek yang diperoleh pihak nasabah. Pada umumnya keuntungan yang diperoleh ditetapkan 
berdasarkan kesepakatan kebua belah pihak yakni antara bank syariah dan nasabah berdasarkan pada rasionalisasi perolehan keuntungan dari pembiayaan proyek.

Makna kedua mengandung pengertian bahwa apabila barang yang dibeli tidak dilakukan secara tunai (cash), maka seolah-olah bank syariah menjadi pihak penanggung piutang nasabah atas barang yang dibelinya. Sementara pihak nasabah memiliki kewajiban untuk melunasi piutangnya kepada pihak bank syariah berdasarkan kesepakatan kedua pihak yakni secara tunai (cash) atau angsuran (credit). Disebabkan adanya kesepakatan tersebut, maka pihak bank syariah memiliki hak mendapatkan kelebihan ( $f e e$ atau mark up) atas tanggungan pembayaran piutang pembelian barang yang dibeli oleh nasabah. Umumnya keuntungan tersebut harus disepakati oleh kedua pihak berdasarkan besaran nilai asal harga barang dengan rasio waktu yang dibutuhkan untuk pelunasan pembayaran (Sunarto Zulkifli:2003).

Secara umum, penerapan prinsip hiwalah dalam produk bai' al-istishna dan bai' al-salam tersebut seolah-olah hampir sama maknanya dengan akad murabahah sebagai suatu akad pembelian barang dengan cara angsuran (credit) dan adanya kelebihan (mark up) dari harga asal. Bedanya dalam murabahah, setiap pembelian dengan cara kredit umumnya dilakukan dengan syarat Uang Muka (UM) atau Dana Permulaan (DP), sedangkan dalam hiwalah pihak nasabah tidak punya kewajiban menyediakan Uang Muka (UM) atau Dana Permulaan (DP). Semua bentuk pertanggungan piutang yang diberikan oleh pihak bank syariah kepada nasabah tidak didasarkan pada UM/DP, melainkan kepada pendapatan keuntungan harga jual atau nilai keuntungan dari proyek yang akan diperoleh dari nasabah sebagai pihak yang tanggung piutangnya oleh bank syariah. Hingga saat ini dilakukan modifikasimodifikasi dari konsep dasar akad-akad tersebut sepanjang itu sesuai dengan prinsip dasar ekonomi syariah.

\section{Aplikasi Hiwalah dalam Produk Bai' al-Istishna' di Bank Syariah}

Secara praktis, aplikasi hiwalah dalam bentuk produk bai' al-istishna dapat dilakukan dalam bentuk pengajuan pembiayaan bai' al-istishna di bank syariah. Prosedur teknis bai' al-istishna terletak pada penentuan besaran harga mark up barang yang dibeli dan besaran keuntungan dari pembayaran piutang nasabah. Kedua hal tersebut ditetapkan berdasarkan kesepakatan kedua belah pihak di saat akad 
hiwalah dan bai' al-istishna dilaksanakan. Mekanisme pembiayaan bai' al-istishna di bank syariah sama dengan mmekanisme pembiayaan lainnya, yakni (Habib Nazir Abdullah:2002):

Pertama, dari segi jenisnya pembiayaan bai' al-istishna umumnya dilakukan untuk kepentingan produktif. Yang dimaksud dengan kepentingan produktif adalah pembiayaan bai' al-istishna semata-mata digunakan bagi kepentingan modal proyek, yang akan dikerjakan oleh nasabah sebagai debitur. Dalam hal ini terjadi kontrak kerja di antara tiga pihak, yakni: (a) bank syariah; (b) nasabah (penerima proyek) dan (c) pemberi proyek/tender.

Kedua, persyaratan umum yang biasa berlaku dalam proses pengajuan pembiayaan bai' al-istishna mencakup lima hal: (a) Character, yaitu penilaian selektif terhadap para calon debitur dan mengukur profitabilitas bagi pengembalian kredit; (b) Capacity, yaitu kemampuan pemohon (calon debitur) dalam pengelolaan menunjukan prestasi, baik dari segi kegiatan bisnisnya maupun perilaku usahanya; (c) Capital, yaitu penilaian terhadap modal yang dapat diberikan kepada para calon debitur sesuai dengan kelayakan atas usaha yang akan atau sedang mereka laksanakan; (d) Condition, yaitu keadaan usaha calon debitur yang berkaitan dengan peluang dan prospek usaha mereka dalam mengelola kredit yang diberikan oleh pihak bank syariah; dan (e) Colateral, yaitu adanya jaminan yang diberikan oleh calon debitur kepada pihak bank syariah, baik dari segi kualitas maupun kuantitasnya. Keharusan adanya barang jaminan ini bersifat kondisional.

Ketiga, penentuan besarnya pembiayaan yang diberikan kepada nasabah umumnya mencakup dua pertimbangan berikut: (a) ditetapkan berdasarkan pada kelayakan proyek yang akan dikerjakan oleh nasabah dan besaran biayan yang harus ditanggung bank syariah dengan cara bai' al-istishna; dan (b) pertanggungan piutang dilakukan bank syariah dalam bentuk transaksi bagi hasil menurut bai' al-istishna.

Keempat, limit waktu pengembalian pembiayaan bai' al-istishna dilakukan dalam mekanisme berikut: (a) pengembalian dana pembiayaan bai' al-istishna dilakukan secara berangsur dan ditetapkan berdasarkan kesepakatan pihak nasabah dan bank syariah; (b) jika telah jatuh tempo dan nasabah tidak melunasi tunggakan hutangnya, maka pihak bank syariah dapat menawarkan opsi kedua berupa dispensasi waktu dan atau sita jaminan terhadap barang yang ia beli dengan cara bai' al-istishna. 
Kelima, pengawasan mencakup atas: (a) preventif, yaitu sikap kehati-hatian dan kecermatan pada tahap pembiayaan, pelaksanaan pembiayaan dan administrasi pembiayaan sebelum dan setelah pembiayaan bai' al-istishna diberikan kepada nasabah; (b) depresif, yaitu pengawasan yang dilakukan oleh pihak bank syariah kepada debitur setelah pertanggungan piutang berupa pembiayaan bai' al-istishna dicairkan, terutama berkaitan dengan evaluasi ketepatan waktu nasabah dalam melunasi pembayaran piutangnya. Selebihnya, memupuk ikatan kemitraan usaha yang lebih erat antara pihak bank syariah dengan nasabah, agar terbentuk suatu kepercayaan yang lebih baik di antara kedua belah pihak.

Adapun standar umum yang biasa dilakukan untuk mengajukan bantuan kredit dan pembiayaan bai' al-istishna, umumnya dilakukan dengan cara sebagai berikut (Buchari Alma:2000):

1. Pemohon mengajukan pembiayaan bai' al-istishna dengan mengisi formulir secara lengkap kepada bank syariah, yang mencakup atas:

a. Biodata pemohon lengkap (nama, tempat/tgl lahir, pekerjaan, nomor telepon)

b. Jenis proyek yang akan dibiayai (rumah, gedung atau bangunan fisik lainnya)

c. Besaran biaya proyek yang akan dikerjakan (dihitung dalam mata uang)

d. Kemampuan melunasi piutang (disesuaikan dengan bahi hasil keuntungan)

e. Data pendukung, seperti: Company Profile dan Bukti Pemenang Tender)

f. Melampirkan dokumen yang diperlukan:

1) Photo Copy KTP atau Akta Notaris Badan Hukum Perusahaan (SIUP)

2) Photo Copy Rekening PLN/Telepon

3) Surat Perjanjian Usaha sejenis Akta Penerima Tender Proyek

2. Proposal tersebut diajukan oleh pemohon kepada bank syariah di bagian Divisi Kredit/Pembiayaan.

3. Proposal tersebut selanjutnya akan dikaji secara seksama oleh pihak bank syariah (Credit Analyst), mencakup atas:

a. Jenis proyek yang akan dibiayai.

b. Jumlah skim pembiayan pertanggungan piutang yang diajukan.

c. Kemampuan melunasi kredit (Accountability).

d. Rasio keuntungan dan kerugian (Profitability).

e. Pertimbangan dikabulkan atau tidaknya pembiayaan bai' al-istishna. 
4. Pihak bank syariah akan melakukan survei lapangan kepada si pemohon. Jika hasil survei positif, pengajuan kredit akan dipertimbangkan untuk diterima dan disepakati dalam surat perjanjian.

5. Pemohon melunasi bantuan kredit dan pembiayaan bai' al-istishna sesuai kemampuan dengan cara lunas atau cicilan piutang sesuai dengan waktu yang telah disepakati bersama.

Mekanisme Hiwalah dalam Produk Bai' al-Istishna (BI)

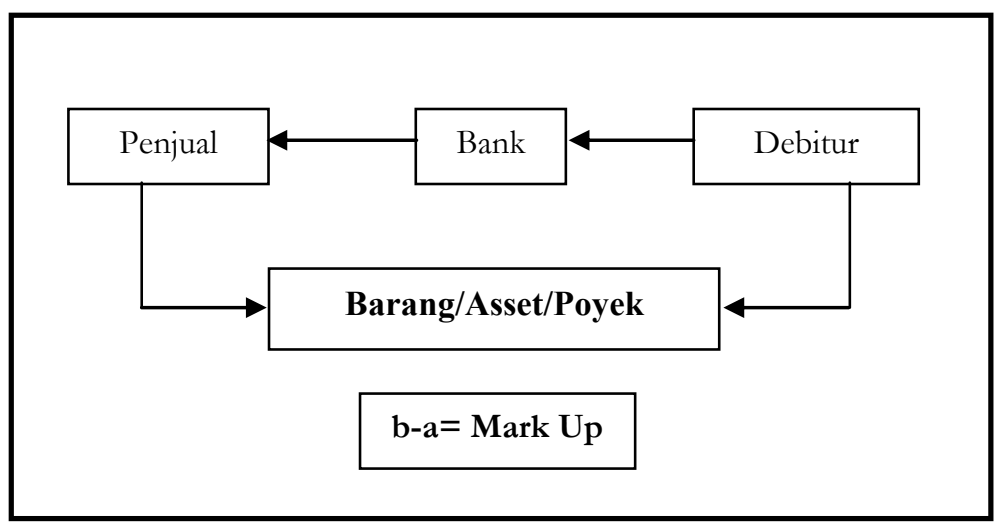

Contoh lainnya adalah dalam akad hiwalah terjadi akad di antara ketiga pihak yakni pihak pertama (orang yang berhutang), pihak kedua (penjamin piutang) dan pihak ketiga adalah pihak yang memberi piutang. Contohnya, Si A membeli barang seharga Rp. 300.000 kepada si B, dan sebelumnya si A menyimpan uang di si C sebesar Rp. 300.000. Kemudian si A dengan C sepakat uang Rp. 300.000 akan dikembalikan untuk melunasi hutang si A kepada si B. Dalam hal ini si C seolah-olah berkewajiban melunasi piutang si A tanpa memberikan kelebihan (mark up) kepada si B. Kasus ini sama dengan penggunaan aplikasi kartu ATM di bank syariah untuk alat pembayaran ke Supermarket. Lebih tegasnya akad hiwalah dapat dilihat dalam skema di bawah ini: 


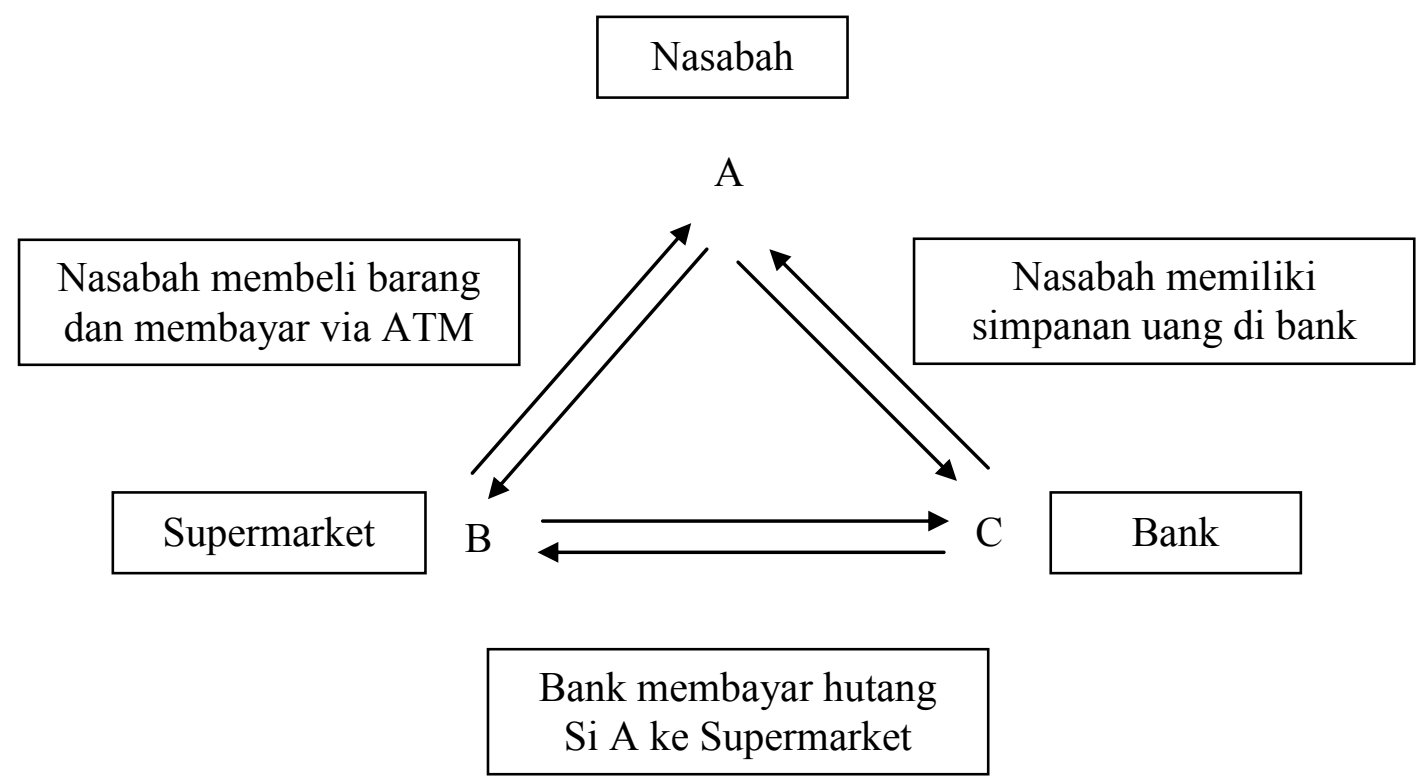

Dari uraian tersebut, tampak bahwa mekanisme pembiayaan pertanggungan piutang dalam akad hiwalah dan bai' al-istishna yang diberikan oleh pihak bank syariah kepada nasabah (perorangan/badan hukum) sesungguhnya tidaklah sesulit seperti yang diperkirakan atau difahami oleh banyak pihak. Hal ini berarti menolak suatu anggapan yang mengatakan bahwa mekanisme pembiayaan pertanggungan piutang dalam akad hiwalah dan bai' al-istishna di bank syariah jauh lebih rumit daripada di lembaga perbankan konvensional.

\section{Analisis Pengembangan Prinsip Hiwalah dan Bai' al-Istishna' di Bank Syariah}

Dalam dunia perbankan modern yang penuh dengan kompetisi, pelayanan dan akuntabilitas merupakan dua aspek penting yang akan membentuk kepercayaan publik terhadap suatu lembaga perbankan. Hal ini mendorong bank syariah untuk membentuk semacam kebijakan (banking policy) untuk merangsang dan memotivasi masyarakat untuk menabung dan menggunakan pelayanan/jasa bank syariah. Saat ini tingkat kepercayaan publik terhadap bank syariah cukup baik dan sekaligus menjadi indikator kesehatan bank syariah itu sendiri. Dengan kata lain, semakin banyak 
masyarakat menggunakan jasa bank syariah, maka akan semakin besar pula nilai keuntungan yang diperoleh oleh kedua belah pihak.

Berkenaan dengan hal tersebut, maka optimalisasi penerapan dan pengembangan prinsip hiwalah tidak hanya dilakukan dalam produk bai' al-istishna, akan tetapi juga dikembangkan dalam bentuk bai' al-salam. Jika bai' al-istishna lebih memprioritaskan pembiayaan pertanggungan piutang nasabah/badan hukum dalam bidang pembiayaan proyek-proyek fisik dan manufaktur, maka bai' al-salam lebih memprioritaskan pada aspek pembiayaan pertanggungan piutang dalam bidang jual beli. Namun bai' al-salam lebih dekat konteksnya dengan bai' al-murabahah, yang sama-sama merupakan produk bank syariah.

Pada prinsipnya, upaya pengembangan produk-produk bank syariah akan dihadapkan kepada beberapa kendala, termasuk juga upaya pengembangan prinsip hiwalah dalam bentuk produk bai' al-istishna dan bai' al-salam di bank syariah akan dihadapkan kepada beberapa faktor pendukung dan penghambat berikut:

\section{Faktor Pendukung}

Di antara faktor-faktor pendukung pengembangan prinsip hiwalah dalam bentuk produk bai' al-istishna dan bai' al-salam di bank syariah, antara lain:

Pertama, semangat kerja seluruh jajaran yang ada di bank syariah, baik dari manajer sampai seluruh karyawannya. Ini merupakan modal utama bagi kemajuan sebuah organisasi apalagi organisasi atau badan usaha seperti bank syariah, tanpa didukung oleh semangat kerja yang tinggi dari seluruh jajaran, maka cita-cita bank syariah untuk meningkatkan kesejahteraan masyarakat muslim yang diridhai Allah SWT akan sia-sia dan tidak akan terwujud. Oleh karena itu diperlukan semangat kerja yang tinggi dalam menyelesaikan bidang muamalah di bank syariah tersebut.

Kedua, kemampuan manajerial yang baik yang dimiliki oleh seluruh jajaran karyawan bank syariah yang memiliki kemampuan manajerial dan teknik pengelolaan keuangan yang tinggi sesuai dengan bidangnya masing-masing. Ini menjadi syarat mutlak untuk mendukung pelayanan yang baik dan maksimal kepada masyarakat pengguna jasa bank syariah.

Ketiga, kejujuran. Di bank syariah diterapkan suatu aturan yang sangat jelas bagi seluruh jajaran direksi dan karyawan. Termasuk didalamnya adanya sistem pemberian penghargaan (reward) terhadap direksi dan karyawan berprestasi dan 
sanksi (punishment) terhadap direksi dan karyawan yang melakukan pelanggaran terutama jika tidak amanah atau tidak jujur.

\section{Faktor Penghambat}

Selain faktor-faktor pendukung itu, bank syariah juga akan dihadapkan kepada faktor-faktor penghambat pengembangan prinsip hiwalah dalam bentuk produk bai' al-istishna dan bai' al-salam, antara lain:

Pertama, masih rendahnya pemahaman masyarakat muslim terhadap prinsip hiwalah dalam produk bai' al-istishna dan bai' al-salam. Sebagaimana diketahui bersama bahwa produk-produk bank syariah di Indonesia, sebagaimana lembaga perbankan syariah lainnya juga menggunakan istilah-istilah yang berasal dari Bahasa Arab, yang bagi sebagian besar segmen masyarakat muslim masih dianggap asing.

Kedua, kurangnya sosialisasi akad hiwalah dalam produk bai' al-istishna dan bai' al-salam. Masyarakat muslim di Indonesia sebagaimana halnya di kota-kota lain lebih mengenal kredit/pembiayaan secara umum di bank konvensional daripada aplikasi hiwalah dalam produk bai' al-istishna dan bai' al-salam di bank syariah.

Ketiga, masih lemahnya jaringan kerjasama bank syariah dengan bank-bank lainnya serta dengan perusahaan-perusahaan publik dalam mengakomodasi kebutuhan pembiayaan modal mereka. Ini harus diantisipasi dengan kerjasama yang lebih baik dan kuat antar lembaga keuangan syariah dan non-syariah di Indonesia.

Keempat, belum lengkapnya pelayanan fitur-fitur yang menarik masyarakat untuk membuka akses bagi penggunaan aplikasi hiwalah dalam produk bai alistishna dan bai' al-salam di bank syariah, yang bisa diakses secara luas dan online melalui jalur internet.

Kelima, belum optimalnya fasilitas rill online antar cabang bank syariah atau dengan bank-bank lainnya. Padahal aspek pemnafaatan teknologi sesungguhnya merupakan prasyarat mutlak bagi efisiensi dan efektifitas pelayanan kepada masyarakat. Adakalanya keterbatasan teknologi dapat menghambat optimalisasi pelayanan produk dan jasa bank syariah kepada masyarakat penggunanya, baik itu perorangan maupun perusahaan berbadan hukum. 


\section{E. Penutup}

Pada bagian akhir ini penulis menyimpulkan sebagai berikut: Pertama, dari segi definisi, hiwalah adalah pemindahan piutang dari tanggung jawab seseorang menjadi tanggung jawab orang lain. Kedua, prinsip hiwalah diaplikasikan di bank syariah dalam bentuk produk bai' al-istishna dan bai' al-salam. Produk bai' alistishna merupakan mekanisme pertanggungan piutang oleh pihak bank syariah kepada pihak nasabah yang memiliki tanggungan utang atas pembiayaan proyekproyek fisik. Bank syariah akan memperoleh keuntungan berdasarkan bagi hasil keuntungan dari proyek yang dikerjakan oleh pihak nasabah. Sedangkan produk bai' al-salam merupakan mekanisme pertanggungan piutang oleh pihak bank syariah kepada pihak nasabah yang melakukan suatu transaksi jual beli tidak secara tunai.

Ketiga, faktor-faktor pendukung pengembangan prinsip hiwalah dalam produk bai' al-istishna dan bai' al-salam di bank syariah adalah kinerja positif seluruh pimpinan, staf dan karyawan bank syariah memiliki komitmen kuat terhadap pengembangan ekonomi syariah, kemampuan manajerial yang baik, dan sikap mental (kejujuran) serta amanah untuk melayanan masyarakat sebaik-baiknya. Sedangkan faktor penghambatnya adalah masih rendahnya tingkat pemahaman masyarakat terhadap bank syariah, kurangnya sosialisasi hiwalah dalam produk bai' al-istishna dan bai' al-salam, masih lemahnya jaringan perbankan syariah dengan bank-bank lain serta belum optimalnya fasilitas pelayanan sistem jaringon antar bank online. 


\section{DAFTAR PUSTAKA}

Antonio. M. Syafi'i, Bank Syariah Dari Teori ke Praktek (Jakarta: Gema Insani, 2001).

Anonimous, "Aplikasi Giro Wadi'ah di Bank Syariah" dalam http://www.bi.co.id

Heri Sudarsono, Bank dan Lembaga Keuangan Syariah (Yogyakarta: Ekonisia, 2004).

Brosur Info Produk Bank Jabar Syariah. (Bandung: Bank Jabar, 2007).

Ibn Hajar al-Asqalani, Bulugh al-Maram (Beirut: Dar al-Fikr, t.th).

Jusuf. Jopie, Panduan Dasar Account Officer (Yogyakarta: UPP AMP YPKN, 2004).

Kasmir, Dasar-dasar Perbankan (Jakarta: Raja Grafindo Persada, 2007).

Karim. Adiwarman, Bank Islam: Analisis Fiqh Keuangan (Jakarta: Raja Grafindo Persada, 2007).

Muhammad, Manajemen Dana Bank Syariah, (Yogyakarta: Ekonisia, 2004)

Soenardjo, dkk, Al-Qur'an dan Terjemahnya (Jakarta: Depag RI, 1992).

Suhendi. Hendi, Pengantar Fikih Muamalah (Jakarta: Rajawali Press, 2002).

Sumitro, Asas-asas Perbankan Islam dan Lembaga Terkait, (Jakarta: Raja Grafindo Persada, 2002).

Zulkifli. Sunarto, Pernbank Syariah (Jakarta: Dzikrul Hakim, 2003). 


\section{CURRICULUM VITAE}

T. Abrar ZA, Syihab, Lahir di Banda Aceh, 26 Agustus 1976, adalah alumni Fakultas Syariah IAIN Sunan Gunung Djati Banten Prodi Perdata Pidana Islam, Mahasiswa Pasca IAIN Sumatera Utara Medan program Studi Ekonomi Islam. Kesibukan Penulis adalah Dosen tetap di Fakultas Ekonomi Islam IAIAl-muslim Matang, sebagai staf pengajar di Fakultas Syariah STAIN Malikussaleh, staf Pengajar di F-KIP Al-Muslim Lhokseumawe, 2006 s/d 2009, staf Pengajar di Fakultas Tarbiyah Universitas Muhammadiyah Aceh (UNMUHA) unit Panton Labu, staf pengajar di STIS Jamiatut Tarbiyah Lhoksukon, staf Pengajar di Universitas Islam Tamiang (UIT). Pengalaman Organisasi adalah Tahun 1994-1996 Pengurus Himpunan Mahasiswa Islam (HMI) Komisariat Fak. Syariah Sunan Gunung Djati Banten, Tahun 1995-1997 Sekretaris Umum Gema Seni Budaya Islam Kampus (GESBICA) IAIN Sunan Gunung Djati Banten, Tahun 1996-1998 Koordinator Ikatan Musisi Muda Banten (IMMB), Tahun 1999-2004 Wakil Ketua Gerakan Pemuda Ansor (GP ANSOR) Jakarta Timur, Tahun 20012002 Anggota Ikatan Advokasi (IKADIN) Jakarta Timur. 